\title{
Experience and Implications from Korean Industrial Structure Adjustment
}

\author{
Lingna Mo, Hailin Zhu, Jia Liang and Miao Ding
}

\begin{abstract}
Optimization and upgrading of industrial structure, for a country or region's economic development, social progress, the promotion of regional economic competitiveness and economic and social sustainable development, has a very important practical significance. Optimization and upgrading of industrial structure is an important prerequisite for accelerating economic development, and an important way to enhance regional economic competitiveness, and it is the inevitable choice of sustainable development of economy and society. This paper studies the Practice and Experience in the optimization and upgrading of industrial structure in Korea, which has a certain theoretical and practical significance for the optimization and upgrading of regional industrial structure in China.
\end{abstract}

Keywords-Experience and Implications Industrial Structure Adjustment Korea

\section{IMPLEMENTATION OF THE GOVERNMENT-LED}

\section{MARKET ECONOMY}

The central government plays an important role in the industrial layout in the region, and Korea established a government-led market economy. Before the 1980s, South Korea planned to rely on national guidance intervention to a great extent directly from the government industrial policies department to make and execute, but there were significant national direct physical plans and policies. After the 1980s, South Korea had given up the direct intervention of the state to determine the industrial policy through legislation. It can be said that the rapid development of the South Korea's economy was attributed to Government policies on industrial policy, technology innovation, and industrial cluster policy.

\section{THE IMPLEMENTATION OF THE STRATEGIC BUSINESS}

\section{GROUP}

South Korea is one of the countries that pay attention to the development of

\footnotetext{
Lingna MO: 1963-, Professor, Master of Economy and Management, Deputy Director of Department of Finance and Economy, Guangxi University of Science and Technology, China, the direction of research: Knowledge-driven economy and innovation management
}

Hailin Zhu: 1990-, Graduate students, Guangxi University of Science and Technology, the direction of research: Knowledge-driven economy and innovation

Jia Liang: 1987-, Teacher, Lushan College of Guangxi
University of Science and Technology, is mainly engaged in the accounting audit.

Miao Ding: 1990- Graduate students, Guangxi University of Science and Technology, the direction of research: Knowledge-driven economy and innovationheadquarters economy earlier, in order to achieve economic growth target. From the 1970s, the government took a variety of financial, credit, trade and other incentives, to support a number of large enterprise groups, reducing the dispersion of capital and not savings, and increasing the concentration of capital. The development of South Korea's economic was inseparable to the South Korean government-led market economy and the implementation of the Enterprise Group strategy. The rapid growth of large enterprise groups to make Korean products to enhance the international competitiveness and exports, led the development of various industrial sectors, and promoted the growth of South Korea's economy.

\section{IMPLEMENTATION OF PRIORITY DEVELOPMENT \\ "STRATEGIC INDUSTRIES" POLICY}

The South Korean government plays a decisive role in the choice of the leading industry and the formation and development of the industry. In 1960s, the Korean economy initial stage, was introduced an inclination industrial policy which was paying more attention to industry than agriculture, and paying more attention to export more domestic demand; Between 1972 to 1979, South Korea's industrial policy tended to heavy industry, established ten strategic industries as steel, fiber, cars, etc., to ensure the smooth transition from the industrial structure of the textile industry to heavy industry; after the 1980s, the international situation has changed, South Korea had proposed development of technology and knowledge-intensive industry; In the 21st century, South Korea laid IT industry as a key development industries, and introduced a series of measures. Early in June 1996, South Korea developed a "Promoting Informatization Basic Plan"; in 1999, with the knowledge economy has become a new model of development, South Korea has modified the plan, published "Network of South Korea in the 21st century" program, planned in 2005 to complete the construction of ultra-high-speed communications network, to fully realize the information. Currently, semiconductors, liquid crystal displays, mobile communication terminal has become South Korea's main export commodity. South Korea also plans to invest in the development focus fourth generation mobile communication, information protection system, the core technology in the next five years to promote the information technology industry continues to be the main driving force of the Korean economy, and create 
employment opportunities. Throughout the history of Korean industry, we can see that the South Korean government to take in a particular stage is selective, to focus on industrial policy.

\section{FOCUSED ON THE UPGRADING OF TRADITIONAL}

\section{INDUSTRIES}

Fiber textile industry used to be one of South Korea's strategic industries, but in the early 90 s of last century, due to fierce competition from China and other Asian countries, South Korea's share of textile products in the international market began to decline, and many Korean fiber products companies have transferred production bases to low production cost countries and regions, so the South Korean government departments and fiber business organization began to adjust the structure of the industry, in particular to adjust product structure, organized fiber, fiber, dyeing and textile enterprises collaborate, cooperation and strengthening the development of new technology products. Established South Korea dyeing technology research institute, South Korea fiber dyeing industrial park, surrounding dyeing industrial park, formed from the dyeing, color matching, digital technology development, centralized sewage treatment, heat supply and other integrated research and development and application, set production, research, science as one of the high-tech research and development center and production center.

\section{EMPHASIZED TAX LEGISLATION}

In 1967, the Korean government formulated the "Science and Technology Promotion Act" to strengthen the role of taxation in promoting scientific and technological progress and economic development. In 1974, the government promulgated the "new technology industry investment tax deduction system", which is a direct tax incentive law maked by South Korean government for the support and the development of key industries. In 1977 and 1979, South Korea established the "research equipment investment tax deduction system" and "technology transfer tax relief system". In 1974, in order to simplify the tax system, South Korea implemented the "key sectors of the special tax treatment", the key departments had the right to choose one of the three in the tax exemption, special depreciation, investment tax credit. Exemption period is defined as: the first year to third year not levy corporate tax, fourth and fifth years minus half the tax. The provisions of the investment tax credit for: the domestic production of machinery, equipment investment deal on a $10 \%$ tax credit, for not domestic production machinery, equipment investment credit at a rate of $8 \%$. Special depreciation system provides a $100 \%$ allowance for depreciation of fixed assets, the industries who can enjoy preferential is the focus of the industry such as the iron and steel, chemical fertilizer, electronics, petrochemical, shipbuilding, water supply, gas supply and others.

\section{ENCOURAGING TECHNOLOGY INNOVATION}

A. The Implementation of Preferential Tax Incentives

\section{for Technological Development.}

In the development of technology, South Korea promulgated the "Technology Research and Development Promotion Law" in 1973, after 1977 and 1981 twice revised, it has become constantly perfect. The main incentives which proposed in the Act included: exempting from annual research and development of non-capital tax developed; reducing the import duties for research and development of equipment; exempting from corporate research organization of real estate land tax; reducing the investment tax.

\section{B. Research and Development Expenses Tax Deduction and Accelerated Depreciation Test Equipment.}

Personnel expenses business full-time research staff, study materials costs, foreign delegate education and training expenses, research expenses, the cost of vocational training within the company, can enjoy a tax deduction before income taxes. If the tax deductions deductible deficiency, it can carry-forward within five years and seven years. For enterprise research and test equipment can be used accelerated depreciation or tax deduction method.

\section{Development of New Technologies and Tax Relief Turnover Tax}

Experimental study on Enterprise Institute, Industrial Technology Research Group and the non-profit corporation and other units for new product development, and can not be produced with the goods must be imported which exempted from special consumption tax. Enterprise Institute for Real Estate exempt from local taxes. Foreign technical service personnel for domestic services exempt from personal income tax treatment for 5 years. Enterprise dedicated research and development institutions and industrial technology development department, imports for scientific research or industrial development items, give preferential tariff reductions.

\section{ENCOURAGING SCIENTIFIC AND TECHNOLOGICAL}

\section{ACHIEVEMENTS TO THE MARKET AND}

\section{INDUSTRIALIZATION}

\section{A. The Transfer of Technology and Market Development Income Tax Relief System}

According to South Korea, "tax limitation law exception", the resulting reduction of the scope of technology transfer include: applying for a patent or utility model nationals of the technology transfer or rental income, income from transfer of technology process of self-development. For the transfer to the national income people, to give full exempt from personal income tax or corporate income tax treatment. To adapt to the development in the market of technology transfer products, special consumption tax breaks given preferential treatment.

\section{B. Promote Domestic Technology Industry Incentives}


For a certain percentage of investment in new technology industries, carry out a tax credit and other benefits. They include: Domestic support projects included technology products, to meet the requirements to register the utility model, domestic patented technology, research institutions, and non-profit legal nature of the development of technological achievements.

\section{The Development of Technology-Intensive Enterprises to Give Tax Breaks}

They include: new technologies identified by the Ministry of Science and technology projects domestic needs determined by tender; research government research institutions, Enterprise Institute, a non-profit research institutes and universities; MOCIE confirmed their support for the project through a tender; by registering utility model projects; in accordance with the relevant laws and the introduction of foreign technology.

\section{VIII.PAY ATTENTION TO THE ADJUSTMENT OF INDUSTRIAL}

\section{UPGRADING SOCIAL INCOME DISTRIBUTION GAP}

\section{PERIOD}

In the period of heavy and chemical industries and export-oriented, labor-intensive industries to capital-intensive industry restructuring led to the deterioration of social income distribution. The South Korean government has taken a number of measures aiming at increasing the welfare of low-income people, including tax reform, and the main measures are: they implemented a part of comprehensive personal income tax system in 1967, the tax rate increased grade (from 5 to 7 -speed gear), in order to increase high-income tax burden, while increasing wage earners' allowance.

\section{PROTECT DOMESTIC MARKETS AND THE}

\section{IMPLEMENTATION OF POLICIES TO EXPAND EXPORTS}

In the 1960s, the South Korean government took "individual bred" approach to limit funds and foreign exchange tilted to large enterprises, in order to improve the international competitiveness of domestic enterprises. Export-oriented industrialization has always been an important pillar of the South Korean government policy. Government procurement policy is also an important policy to protect the domestic market. For domestic high-speed trains and nuclear power plants and other utility equipment, they are all purchased by the Korean government. The introduction of high-speed trains in government regulations, except in accordance with the provisions of the contract from France's 10 train, the other 34 units must be completely purchased localization of products. Automotive, computer products, government regulation of domestic product higher prices are in precedence.

\section{REFERENCES}

[1] The Industrial History of Korea

[2] Korea Statistical Yearbook in1964-2014

[3] History of Korea Industrial Policy Changes 